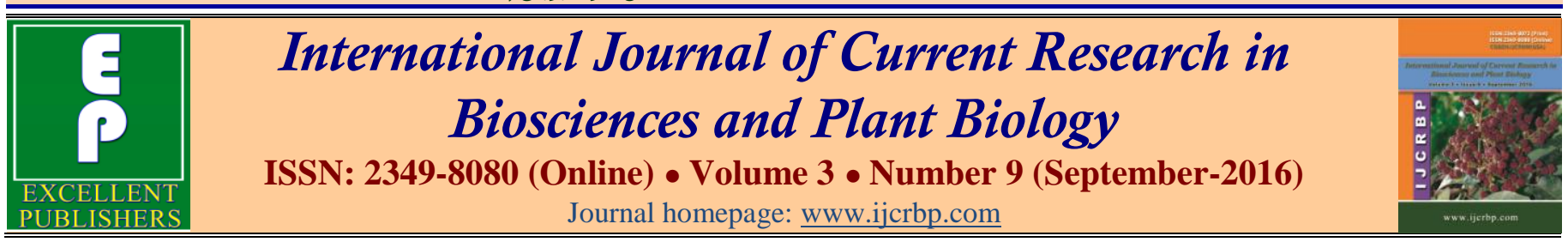

Original Research Article

doi: http://dx.doi.org/10.20546/ijcrbp.2016.309.002

\title{
Zoogeographic Analysis of Fishes Associated with Soft Bottoms in San Ignacio Lagoon, Baja California Sur, Mexico
}

\section{Pablo Kosegarten-Villarreal, Emelio Barjau González*, Oscar Trujillo Millán and Eleonora Romero Vadillo}

Departamento Académico de Ciencias Marinas y Costeras, Universidad Autónoma de Baja California Sur, Km. 5.5 Carretera al Sur. CP 23080. La Paz, B.C.S., Mexico

*Corresponding author.

\begin{abstract}
A b s tract
San Ignacio Lagoon is located on the west coast of Baja California Sur; this body of water has important bio-economic properties. Because of its geographical location, it is considered to be a part of the Californian province temperate region. There have been several studies of the fish fauna present in the lagoons of Baja California Sur, however, the information collected so far is not enough to provide good management and conservation of the fish fauna of this lagoon. This study established the zoogeographic affinities of fish species associated to soft bottoms registered in San Ignacio Lagoon B.C.S. Six samplings were conducted at 11 sites in the lagoon, from April 2013 to April 2014; an experimental trawl was used and the physicochemical parameters were obtained at each sampling. A total of 2887 organisms from 26 families, 38 genera and 46 species of fishes were collected, the largest number of species were from the Haemulidae and Serranidae families. The zoogeographic affinities correspond to $28 \%$ Californian Province, 4\% Cortez Province, 7\% Mexican Province, 41\% Panamic Province, $18 \%$ Eastern Pacific and 2\% Circumtropical.
\end{abstract}

\section{Introduction}

Mexico has $12,500 \mathrm{~km}^{2}$ of coastal lagoons; this represents 30 to $35 \%$ of the national territory (Acevedo, 1997). The coastal lagoons have permanent or ephemeral communication with the sea, and are the encounter between two bodies of water with different oceanographic characteristics, causing particular physico-chemical and biological properties, and their consequent ecological patterns (Contreras, 1988).

The study of the fish fauna in coastal lagoons is important because of their high economic value (Acevedo, 1997). These organisms have reproductive, feeding and migration patterns that are related to the physicochemical processes and the heterogeneity and

\author{
Article Info \\ Accepted: 08 August 2016

\section{Keywords} \\ Biogeography \\ Eastern Pacific \\ Ichthyofauna \\ Zoogeographic affinities
}

Available Online: 06 September 2016 productivity of these systems (Martínez, 2008). San Ignacio Lagoon is located on the west coast of Baja California Sur, Mexico; in addition to their ecological importance, this body of water has important bioeconomic properties, including fishing and ecotourism activities, which highlight the need for good management and conservation of the area (De la CruzAgüero, 2000). Because of its geographical location this coastal lagoon is located in the temperate region, and according to Briggs (1974), from a zoogeographical point of view, belongs to the Californian province.

Danemann and De la Cruz-Agüero (1993) made a list of the fish fauna of San Ignacio Lagoon, and registered 81 species of fishes obtained from analysis of eating habits of birds, prospecting collections and samples granted by 
fishermen; De la Cruz-Agüero and Cota-Gómez (1998) updated the list of fishes registered in San Ignacio Lagoon, adding 26 species resulting in a total of 107 species.

Galván-Magaña et al. (2000) did a study of affinities that included the analysis of five coastal lagoons of Baja California Sur, finding a total of 723 species, classified according to their provinces, and found that species of temperate affinity are more abundant in the northern lagoons and decrease at lower latitudes.

Martínez (2008) analyzed the fish diversity and biogeographic patterns of San Ignacio Lagoon, concluding that there is a transition of biogeographic areas and fishes from different provinces can be found there. Barjau-González et al. (2014) conducted a study about the structure of fish fauna associated to soft bottoms in San Ignacio Lagoon, finding 44 species, most of them with tropical affinity.

The research related to the zoogeographic characterization of the ichthyofauna of the coast of Baja California Sur, including San Ignacio Lagoon, is outdated. Particularly, the information about fishes associated to soft bottoms in this lagoon is insufficient. Therefore, the present study pretends to establish the zoogeographic affinities of fish species associated to soft bottoms in San Ignacio Lagoon, B.C.S., during 2013-2014.

\section{Materials and methods}

San Ignacio Lagoon is located on the west coast of the Baja California Peninsula. It is located between $26^{\circ} 38^{\prime}$ and $27^{\circ}$ North latitude, and $113^{\circ} 08^{\prime}$ and $113^{\circ} 18^{\prime}$ West longitude (Danemann, 1994) (Fig.1).

It is a body of shallow water, with an area of $175 \mathrm{~km}^{2}$ and depths of 2 to $4 \mathrm{~m}$ over most of its area. However, the channels that connect it with the ocean have depths up to $20 \mathrm{~m}$ (Garate-Lizárraga et al., 2001). In its lower region, the lagoon divides into two arms, one of them goes up north and forms the main body of water; and the other goes southeast and is characterized by abundant mangrove and deep channels (Danemann, 1994).

Six samplings were performed in the months of April, June, August, October and December 2013 and April 2014. Each sampling was conducted at 11 sites, performing a total of 66 replicas (Fig.1). Fishes were caught with an experimental net, with a length of $9 \mathrm{~m}$ and $4.5 \mathrm{~m}$ wide, 1.5 inches of mesh and $95 \times 50 \mathrm{~cm}$ metal doors. Towing speed was $3.5 \mathrm{~km} / \mathrm{h}$, performing a sweep of 20 minutes at each site, using a 22 feet long outboard motor boat of $75 \mathrm{Hp}$. The average depth at which the scans were performed was $5 \mathrm{~m}$. Salinity and temperature data were obtained from the bottom at each sampling site, using a YSI 2030 Pro multiparameter meter. The fish species were identified using specialized literature (Miller and Lea, 1972; Fischer et al., 1995a, b; Thomson et al., 2000).

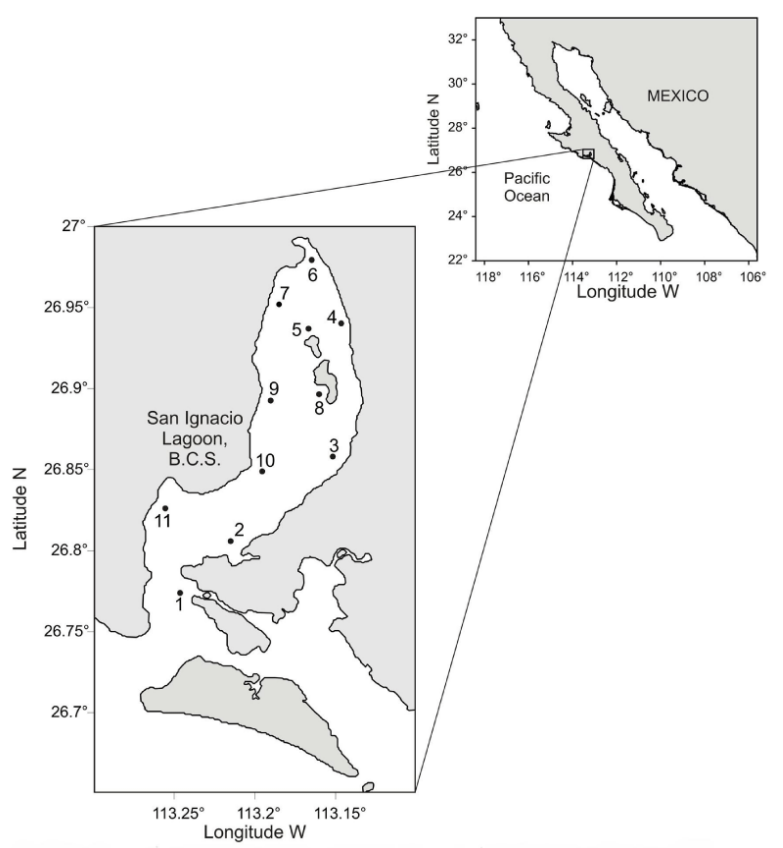

Fig. 1: Study area and sampling sites in San Ignacio Lagoon, Baja California Sur, Mexico.

The determination of the zoogeographic affinity of the species identified in the study area was based on the characterization of their distribution according to the basic outline of the work by Hubbs (1960), Rosenblatt (1967) and Briggs (1974), with modifications by Boschi (2000), Galvan-Magaña et al. (2000), Hastings (2000), Robertson and Allen (2002), Robertson et al. (2004), Horn et al. (2006) and Robertson and Cramer (2009), considering the following provinces:

1. Californian Province: fishes with a distribution in the temperate-warm zone, that ranges from Magdalena Bay up to northern California in the United States.

2. Mexican Province: includes species that are distributed from Magdalena Bay and Cabo San Lucas, B.C.S., down to The Isthmus of Tehuantepec, Oaxaca.

3. Cortez Province: mainly includes species of the Gulf of California, with a southern boundary in Cabo San Lucas on its western portion, and Mazatlan in its eastern portion. 
4. Panamic Province: fish species that are distributed in the subtropical-tropical zone, from $23^{\circ} \mathrm{N}$ to $5^{\circ} \mathrm{S}$ in Peru.

5. Eastern Pacific: fish widely distributed in the Eastern tropical-temperate Pacific from California to Peru.

6. Circumtropical: fish widely distributed in all tropical seas of the world.

\section{Statistical analysis}

Statistical analysis was performed using Statistica v.8. One way ANOVA was used to determine significant differences in temperature and salinity, per month and per locality. Those with significant differences were analyzed through a multiple comparison test using the Fischer method.

\section{Results}

\section{Physico-chemical parameters}

Significant variations in temperature per month were observed $[\mathrm{F}(5.60)=107.31, p<0.05)$. The highest average was registered in August $\left(25.2^{\circ} \mathrm{C}\right)$ and the lowest was registered in December $\left(16.3^{\circ} \mathrm{C}\right)$. From April to August of 2013, the temperature increased, reaching its peak in the summer months (August) and thereafter decreases to the minimum temperature in late autumn and early winter (December); increasing again until April 2014. According to the sites analyzed, La Base had the highest average temperature $\left(22.45^{\circ} \mathrm{C}\right)$, and the lowest was recorded at Canal El Cardón $\left(19.68^{\circ} \mathrm{C}\right)$. There were no significant differences in temperature between sites $[\mathrm{F}(10.55)=0.3163, p>0.05]$.

Salinity per month, also showed significant differences $[\mathrm{F}(5.60)=18.3754, p<0.05]$. The highest average was in June (38\%) and the lowest in April 2014 (31.1\%). It is noted that from April 2013 until August 2013, the salinity had a tendency to increase, reaching its peak in the summer months (June) and thereafter decreases to the minimum salinity in spring (April 2014). Also, there were no significant differences between sites [F (10.55) $=1.5622, p>0.05]$, with a range of 32.78 to $36.97 \%$.

\section{Zoogeographic affinity}

A total of 2887 fishes from 26 families, 38 genera and 46 species, were collected. Families that contributed with a greater number of species were: Haemulidae and Serranidae with five species each; Sciaenidae with four species, followed by Paralichthydae and Clupeidae with three species each. The remaining families contributed only with one or two species. Based on the analysis, of the 46 species recorded, $41 \%$ belongs to the Panamic Province, $28 \%$ to the California Province, $18 \%$ to the Eastern Pacific, $7 \%$ to the Mexican Province, $4 \%$ to the Province of Cortez and 2\% are Circumtropical (Fig. 2). Also, $72 \%$ had tropical affinity, while the remaining $28 \%$ showed preference to temperate waters.

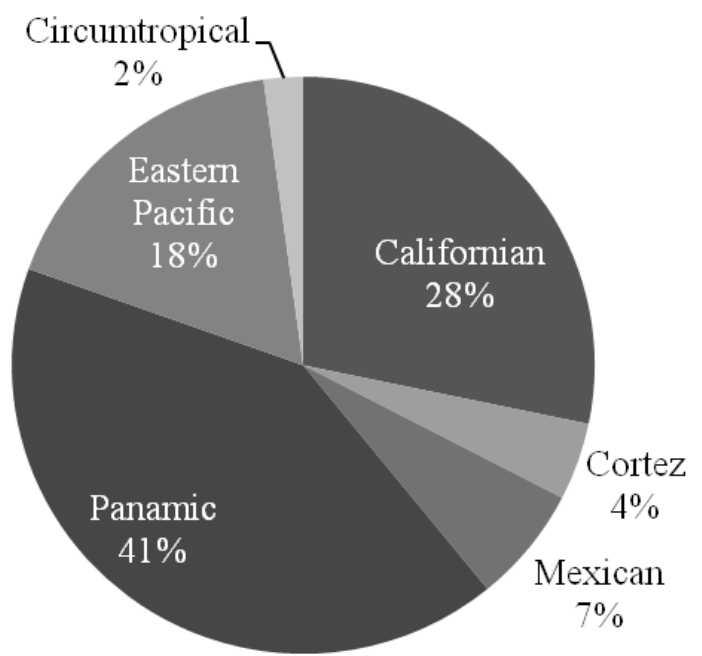

Fig. 2: Affinity percentage by zoogeographic province.

According to the analysis of presence/absence, different species were found each season. Although, there were more species with tropical affinity than species with temperate affinity. Pleuronichthys guttulatus, Calamus brachysomus, Chaetodipterus zonatus and Sphoeroiedes annulatus were always present. Three species were recorded in five samplings, three species in four samplings, five species in three samplings, three species in two samplings and 28 species were found only in one sampling (Table 1).

The analysis per month showed a different number of species with tropical and temperate affinities. In April 2013, 15 species were recorded, nine $(60 \%)$ were tropical and six (40\%) were of temperate affinity. In June, 15 species were recorded, nine (60\%) were tropical, and six (40\%) with temperate affinity. In August, 23 species were recorded, 18 (78.3\%) were tropical, and five $(21.7 \%)$ with temperate affinity. In October, 23 species were recorded, $16(69.5 \%)$ were tropical, and seven $(30.5 \%)$ with temperate affinity. In December, a decrease in the number of species was observed, with only 10 species recorded, six $(60 \%)$ were tropical and four (40\%) were temperate. Finally, in April 2014, 14 species were recorded, $10(71.4 \%)$ were tropical and four (28.6\%) were temperate (Fig. 3). 
Table 1. Presence (1)/absence (0) of fish species recorded during the sampling at San Ignacio Lagoon.

\begin{tabular}{|c|c|c|c|c|c|c|}
\hline Species & Apr-13 & Jun-13 & Aug-13 & Oct-13 & Dec-13 & Apr-14 \\
\hline Atherinops affinis & 0 & 0 & 0 & 0 & 1 & 0 \\
\hline Atractoscion nobilis & 1 & 0 & 0 & 0 & 0 & 0 \\
\hline Haemulon californiensis & 1 & 0 & 1 & 1 & 0 & 0 \\
\hline Halichoeres semicinctus & 0 & 1 & 0 & 1 & 0 & 0 \\
\hline Pleuronichthys guttulatus & 1 & 1 & 1 & 1 & 1 & 1 \\
\hline Leuresthes tenuis & 0 & 0 & 0 & 0 & 1 & 0 \\
\hline Myliobatis californica & 0 & 0 & 0 & 1 & 0 & 0 \\
\hline Paralabrax auroguttatus & 0 & 0 & 0 & 1 & 0 & 0 \\
\hline Paralabrax maculatofasciatus & 1 & 1 & 1 & 1 & 0 & 1 \\
\hline Paralabrax nebulifer & 1 & 1 & 1 & 1 & 0 & 1 \\
\hline Paralichthys californicus & 1 & 1 & 1 & 0 & 0 & 1 \\
\hline Pleuronichthys verticalis & 0 & 1 & 0 & 0 & 0 & 0 \\
\hline Sardinops caeruleus & 0 & 0 & 0 & 0 & 1 & 0 \\
\hline Anchoa ischana & 0 & 1 & 1 & 1 & 0 & 0 \\
\hline Ancylopsetta dendritica & 0 & 0 & 1 & 0 & 0 & 0 \\
\hline Balistes polylepis & 0 & 1 & 1 & 1 & 0 & 0 \\
\hline Calamus brachysomus & 1 & 1 & 1 & 1 & 1 & 1 \\
\hline Chaetodipterus zonatus & 1 & 1 & 1 & 1 & 1 & 1 \\
\hline Cynoscion phoxocephalus & 0 & 0 & 1 & 0 & 0 & 0 \\
\hline Cynoscion xanthulus & 0 & 0 & 0 & 1 & 0 & 0 \\
\hline Dasyatis longus & 0 & 0 & 1 & 1 & 0 & 0 \\
\hline Epinephelus itajara & 0 & 0 & 0 & 0 & 0 & 1 \\
\hline Etropus crossotus & 0 & 0 & 1 & 0 & 0 & 0 \\
\hline Etrumeus teres & 0 & 0 & 0 & 0 & 1 & 0 \\
\hline Eucinostomus currani & 0 & 1 & 1 & 1 & 0 & 1 \\
\hline Eucinostomus dowii & 1 & 0 & 0 & 0 & 0 & 0 \\
\hline Exerpes asper & 0 & 0 & 0 & 0 & 0 & 1 \\
\hline Gymnura marmorata & 1 & 0 & 1 & 0 & 0 & 1 \\
\hline Haemulon flaviguttatum & 1 & 0 & 0 & 0 & 0 & 0 \\
\hline Hippocampus ingens & 1 & 0 & 1 & 1 & 0 & 0 \\
\hline Microlepidotus inornatus & 0 & 0 & 0 & 1 & 0 & 0 \\
\hline Mugil curema & 0 & 0 & 0 & 0 & 1 & 0 \\
\hline Narcine entemedor & 0 & 0 & 1 & 0 & 0 & 0 \\
\hline Opistonema libertrate & 0 & 0 & 0 & 1 & 0 & 0 \\
\hline Orthopristis chalceus & 0 & 0 & 0 & 1 & 0 & 0 \\
\hline Orthopristis reddingi & 0 & 0 & 1 & 0 & 0 & 1 \\
\hline Paralonchurus goodei & 0 & 0 & 1 & 0 & 0 & 0 \\
\hline Perissias taeniopterus & 0 & 0 & 1 & 0 & 0 & 0 \\
\hline Rhinoptera steindachneri & 0 & 0 & 0 & 1 & 0 & 0 \\
\hline Selene brevoortii & 0 & 1 & 0 & 0 & 0 & 0 \\
\hline Serranus psittasinus & 0 & 0 & 0 & 0 & 1 & 0 \\
\hline Syngnathus auliscus & 0 & 0 & 0 & 1 & 0 & 0 \\
\hline Sphoeroides lobatus & 1 & 1 & 1 & 1 & 0 & 1 \\
\hline Sphoeroiedes annulatus & 1 & 1 & 1 & 1 & 1 & 1 \\
\hline Sphyraena lucasana & 1 & 0 & 0 & 0 & 0 & 0 \\
\hline Urobatis halleri & 0 & 1 & 1 & 1 & 0 & 1 \\
\hline
\end{tabular}




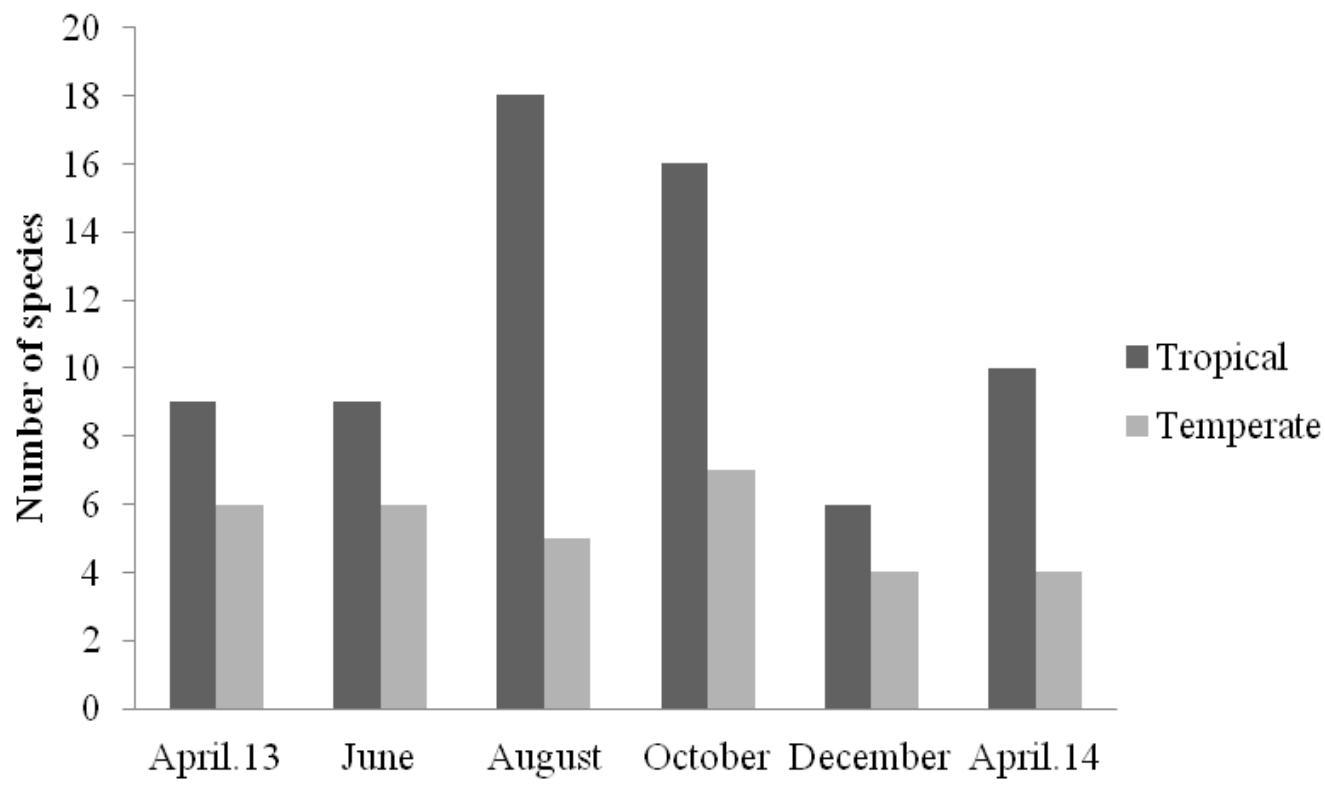

Fig. 3: Number of species of tropical and temperate affinity captured during the months of sampling in San Ignacio Lagoon.

\section{Discussion}

The maximum temperature in the lagoon was during the summer months $\left(28.5^{\circ} \mathrm{C}\right)$ in the period of $1992-1993$ (Segura-Zarzosa et al., 1997) and $25^{\circ} \mathrm{C}$ in $1998-1999$ (Barjau-González, 2003). The latter is similar to the one recorded in the present study $\left(25.2^{\circ} \mathrm{C}\right)$. On the contrary, the minimum temperature recorded in 1992-1993 was $15.8^{\circ} \mathrm{C}$ (Nuñez-López, 1996) and $11.2^{\circ} \mathrm{C}$ during 1998 1999 (Barjau-González, 2003). The latter represents a difference of $5^{\circ} \mathrm{C}$ less than the one recorded in this study $\left(16.3^{\circ} \mathrm{C}\right)$, but when compared to the temperature registered 20 years ago, there is only a difference of $0.5^{\circ} \mathrm{C}$. De la Cruz-Agüero (2000) explains that these temperature variations throughout the years allow the entry of some species to coastal lagoons, causing changes in the fish fauna.

Regarding salinity, Largier et al. (1997) classifies San Ignacio Lagoon as hypersaline, noting that in this type of water bodies, high evaporation and little freshwater input generates water with higher salinity that because of its density is directed toward the bottom and out of the lagoon, while less dense water enters through the surface. Also, replacement time of water in the lagoon is slow. Based on this, the average salinity in the mouth of the lagoon is lower than the inside of the lagoon. Considering this, salinity and temperature have significant changes over time, reaching extreme values during certain periods of time. These changes influence the presence of different species of fish because temperature, as mentioned by different authors, strongly influences the distribution of coastal fishes. Therefore, some species have an association or affinity in spatial and temporal level, and can be considered as indicators of temperature.

According to Hubbs (1960), the west coast of the Baja California Peninsula is an area that has warm bodies of water, but with a significant presence of upwellings that bring cold water and nutrients to the region. Based on this, Danemann and De la Cruz-Aguero (1993) and De la Cruz-Agüero et al. (1996) conducted a characterization of the fishes in San Ignacio Lagoon, and inferred that the physico-chemical water conditions can modify the boundaries of the distribution of tropical and temperate species, making it possible to have an overlap of species in coastal water bodies.

The species recorded in this study had already been observed inside or near the lagoon for RodríguezRomero et al. (1994), De la Cruz-Agüero et al. (1996), Galvan-Magaña et al. (2000) and Barjau-González et al. (2014). However, not all of them use the same methodology, and according to Bocanegra (1998), depth, type of substrate, and type of gear used for these studies is crucial to determine the species captured.

San Ignacio lagoon is located north of Bahia Magdalena $\left(25^{\circ} \mathrm{N}\right)$, and according to Briggs (1974), is the distribution boundary of fishes with tropical and temperate affinity. However, in San Ignacio Lagoon a 
higher percentage of species with tropical affinity were found, including the coldest months when the percentage of species with temperate affinity increased, but those of tropical affinity were always the majority.

According to Briggs (1974), the study area belongs to the California Province, however, in this study only $28 \%$ of the species resulted with such a northern tendency. Contrasting this results with the study of BarjauGonzalez et al. (2014), which showed $36 \%$ of affinity to the same province, so with an $8 \%$ difference, this may be due to the water temperature and the wide distribution of some species.

The regions and zoogeographic provinces used in this study are similar to those used by Barjau-Gonzalez et al. (2014) and Juaristy-Videgaray et al. (2014), in order to compare the results and be able to give an adequate follow-up to the distribution of fish fauna in San Ignacio Lagoon. However, Mora and Robertson (2005a, b) and Robertson and Cramer (2009) did a review of various studies in the Tropical Eastern Pacific in order to establish provinces that allow a better management of related species to each province, and try to avoid overlap as much as possible. Their studies present parameters that are useful and should be applied to the biogeographical studies of the Eastern Pacific.

If some species have a wide range of distribution does not mean that they have affinity to multiple provinces. Therefore, in order to identify their provinces, other factors have to be considered, such as the amount of biomass of the species present in the region and the evolutionary processes that have led the species to different places (Mora and Robertson, 2005b; Robertson and Cramer, 2009).

Considering this, the zoogeographical provinces to consider in this type of studies must be related to the target species to be captured during the study, for this is also important to consider the art of fishing selected (Martinez, 2008).

\section{Conclusion}

The zoogeographic affinity of the fishes associated to soft bottoms is influenced by the temperature of the San Ignacio Lagoon, which allows the overlap of species of tropical and temperate affinity. There was a greater number of species with tropical than temperate affinity in San Ignacio Lagoon during the 2013-2014 period, despite being considered a temperate zone. The large number of transitory species evidence abrupt changes in salinity and temperature in San Ignacio Lagoon in different seasons.

\section{Conflict of interest statement}

Authors declare that they have no conflict of interest.

\section{Acknowledgement}

Authors acknowledge the Professor Improvement Program (PRODEP) for funding of the project in which this investigation took part, and the assistance of fish technician Enrique Calvillo Espinosa during fish collection. Fishes were collected under the CONAPESCA-INAPESCA permit (No. PPF/DGOPA261/2013).

The samplings performed during this study comply with the current laws of México.

\section{References}

Acevedo, A., 1997. Caracterización ecológica de la comunidad íctica de la Laguna Ojo de Liebre, B. C. S., México. Tesis de Maestría. Instituto Politecnico Nacional.

Barjau-González, E., 2003. Estructura de la ictiofauna asociada a fondos blandos en Laguna San Ignacio, Baja California Sur, México. Tesis de Maestría. Instituto Politecnico Nacional. México.

Barjau-González, E., Galván-Magaña, F., Abitia-Cárdenas, L., Moreno-Sánchez, X., Rodríguez-Romero, J., 2014. Zoogeographic analysis of the fish fauna associated with soft bottom during El Niño-La Niña (98-99) in San Ignacio Lagoon, Baja California Sur, México. Biodivers. Biopros. Dev. 1(3), 1-7.

Bocanegra, N., 1998. Interacciones tróficas de la ictiofauna más abundante en Laguna Ojo de Liebre, B.C.S. México. Tesis de Maestría, México.

Boschi, E.E., 2000. Species of decapods crustaceans and their distribution in the American Marine Zoogeographic provinces. Rev. Invest. Des. Pesq. 13, 1-136.

Briggs, J., 1974. Marine Zoogeography. McGraw-Hill, EUA.

Contreras, F., 1988. Las Lagunas Costeras Mexicanas. Centro de Ecodesarrollo, México.

Danemann, G., 1994. Biología reproductiva del águila pescadora en Isla Ballena, Laguna San Ignacio, Baja California Sur, México. Tesis de Maestría. México.

Danemann, G., De la Cruz-Agüero, J., 1993. Ictiofauna de Laguna San Ignacio, Baja California Sur, México. Ciencias Marinas. 19(3), 333-341.

De la Cruz-Agüero, J., Arellano, M., Cota, V., 1996. Lista sistemática de los peces marinos de las lagunas Ojo de Liebre y Guerrero Negro, BCS y BC, México. Ciencias Marinas. 22(1), 111-128. 
De la Cruz-Agüero, J., 2000. Origen y distribución de la ictiofauna de la Laguna de San Ignacio, Baja California Sur, México. Ciencia Ergo Sum. 7(2), 157-165.

De la Cruz-Agüero, J., Cota-Gómez, V., 1998. Ictiofauna de la Laguna San Ignacio, Baja California Sur, México: Nuevos registros y ampliaciones de ámbito. Ciencias Marinas. 24(3), 353-358.

Fischer, W.F., Krupp, W., Schneider, C., Sommer, Carpenter, K., 1995b. Guía FAO para la identificación de especies para los fines de la pesca. Vol. III. Pacífico centrooriental, Roma, FAO. pp.1201-1803

Fischer, W.F., Krupp, W., Schneider, C., Sommer, K., Carpenter. 1995a. Guía FAO para la identificación de especies para los fines de la pesca. Vol. II. Pacífico centro-oriental. Roma, FAO. pp.647-1200.

Galván-Magaña F., Gutiérrez, F.J., Abitia, L.A., RodríguezRomero, J., 2000. The distribution and affinities of the shorefishes of baja California Sur lagoons. In: Aquatic Ecosystems of Mexico: Status and Scope (Eds.: Munawar, M., Lawrence, S., Munawar, I.F., Malley, D.). Ecovision World Monograph series. Backhuys Publishers, Leiden, The Netherlands. pp.383-398.

Gárate-Lizárraga, I., Hernández-Orozco, M.L., Band-Schmidt, C., Serrano-Casillas, G., 2001. Red tides along the coasts of Baja California Sur, México (1984 to 2001). Oceánides. 16(2), 127-134.

Hastings, P., 2000. Biogeography of the Tropical Eastern Pacific: distribution and phylogeny of Chaenopsid fishes. Zool. J. Linnean Soc. 128, 319-335.

Horn, M., Allen, L., Lea, R., 2006. The Ecology of Marine Fishes: California and Adjacent Waters. University of California Press, EUA.

Hubbs, C.L., 1960. The marine vertebrates of the outer coast. Symposium: The biogeography of the Baja California and adjacent seas. Syst. Zool. 9(3-4), 134-147.

Juaristi-Videgaray, D., Barjau-González, E., Vadillo-Romero, E., Romo-Piñera, A., 2014. Variation in taxonomic diversity of the fish assemblage associated with soft bottoms in Laguna San Ignacio, Baja California Sur, Mexico. Biodivers. Biopros. Dev. 1(2), 1000118

Largier, J., Hollibaugh, J., Smith, S., 1997. Seasonally hypersaline estuaries in Mediterranean-climate regions. Estuar. Coast. Shelf Sci. 45(6), 789-797.

Martínez, A., 2008. Análisis de la ictiodiversidad y patrones biogeográficos en los sistemas costeros de B. C. S, México. Tesis de Maestría. Instituto Politécnico Nacional, México.

Miller, D., Lea, R., 1972. Guide to the coastal marine fishes of California. Calif. Dept. Fish Game, Fish Bull., EUA.

Mora, C., Robertson, R., 2005a. Factors shaping the range-size frequency distribution of the endemic fish fauna of the tropical Eastern pacific. J. Biogeogr. 32, 277-286.

Mora, C., Robertson, R., 2005b. Causes of latitudinal gradients in species richness; a test with fishes of the tropical Eastern pacific. Ecology. 86(7), 1771-1782.

Nuñez-López, R., 1996. Estructura de la comunidad de macroalgas de la Laguna San Ignacio B.C.S., México. Tesis de Maestría. Instituto Politécnico Nacional, México.

Roberson, D.R., Grove, J.S., McCosker, J.S., 2004. Tropical transpacific shore fishes. Pac. Sci. 58, 507-565.

Robertson, D.R., Allen, G., 2002. Shore fishes of the Tropical Eastern pacific: an information system. Smithsonian Tropical Research Institute, Balboa, Panamá.

Robertson, D.R., Cramer, K.L., 2009. Shore fishes and biogeographic subdivisions of the tropical Eastern pacific . Mar. Ecol. Prog. Ser. 380, 1-17.

Rodríguez-Romero, J., Abitia-Cárdenas, L., Galván-Magaña, F., Chávez, H., 1994. Composición, abundancia y riqueza específica de la ictiofauna de Bahía Concepción, Baja California Sur, México. Ciencias Marinas. 20(3), 321-350.

Rosenblat, R.H., 1967. The zoogeographic relationship of the marine shore fishes of Tropical America. Tud. Trop. Ocenogr. Miami. 5, 579-592.

Segura-Zarzosa, J.C., Galván Magaña, F., Abitia Cárdenas, L.A., 1997. Observaciones sobre la alimentación del tiburón Heterodontus francisci Girard 1854 (Chondrichthyes: Heterodontidae), en Laguna de San Ignacio, Baja California Sur, México. Ciencias Marinas. 23(1), 111-128.

Thomson, S., Findley, L., Kerstitch, A., 2000. Reef Fishes of Sea of Cortez. The Rocky-shore Fishes of the Gulf of California, University of Texas Press, EUA.

\section{How to cite this article:}

Kosegarten-Villarreal, P., Barjau González, E., Millán, O. T., Romero Vadillo, E., 2016. Zoogeographic analysis of fishes associated with soft bottoms in San Ignacio Lagoon, Baja California Sur, Mexico. Int. J. Curr. Res. Biosci. Plant Biol. 3(9), 9-15. doi: http://dx.doi.org/10.20546/ijcrbp.2016.309.002 